\section{IMPLEMENTASI PEMBELAJARAN TERPADU \\ TERHADAP PERKEMBANGAN ANAK USIA DINI \\ DI KB-TK ISLAM AL AZHAR 31 YOGYAKARTA}

\section{THE IMPLEMENTATION OF INTEGRATED LEARNING IN EARLY CHILDHOOD DEVELOPMENT IN KB-TK ISLAM AL AZHAR 31 YOGYAKARTA}

\author{
Avanti Vera Risti Pramudyani, Sugito \\ Universitas Ahmad Dahlan, Universitas Negeri Yogyakarta \\ avantivera@ymail.com, kanggito@yahoo.com
}

\begin{abstract}
Abstrak
Penelitian ini bertujuan untuk mengetahui implementasi pembelajaran terpadu pada pendidikan anak usia dini dan pengaruh pembelajaran terpadu terhadap aspek perkembangan anak. Penelitian ini adalah Penelitian metode kualitatif dengan dengan pendekatan fenomenologis yang mendeskripsikan tentang pemahaman terhadap seseorang diberbagai situasi dimana akan menjadi bagian utama dalam penggambarannya. Teknik pengumpulan data pengamatan peran serta, di mana peneliti berfungsi sebagai instrumen yang tak terpisahkan dengan subjek penelitian untuk melakukan wawancara mendalam, pengamatan terus-menerus dan studi dokumentasi. Analisis data dilakukan dengan model analisis interaktif yang dilakukan melalui empat kegiatan utama yakni: pengumpulan data, reduksi data, penyajian data dan penarikan kesimpulan atau verifikasi. Hasil penelitian menunjukkan Proses pembelajaran terpadu yang dilakukan belum memperlihatkan keterkaitan antara tema dan dilakukan melalui tahapan: kegiatan perencanaan, pelaksanaan, dan evaluasi. Pengaruh pembelajaran terhadap perkembangan anak, bidang yang paling menonjol adalah bidang sosial emosional dengan pengenalan "rewards and punishment".
\end{abstract}

Kata kunci: pembelajaran terpadu, pendidikan anak usia dini, aspek perkembangan anak

\title{
Abstract
}

This study aims to investigate: (1) the implementation of integrated learning in early childhood education, and (2) the impact of integrated learning on the aspects of children's development. The study employed the qualitative method with the phenomenological approach in which the illustration of understanding people in different situation becomes the essential point of the data. The data were collected through participant observations, in which the researcher functioned as the instrument inseparable from the research subjects to carry out in-depth interviews, continuous observations, and documentation study. The data analysis technique was the interactive analysis model conducted in four main activities, namely data collection, data reduction, data display, and conclusion drawing or verification. The research findings are as follows. (1) The implemented integrated learning process has not shown the relation among themes and was conducted through the stages of activity planning, implementation, and evaluation. In terms of the impact of learning on children's development, the most outstanding areas are the emotional and social areas using the introduction to rewards and punishments.

Keywords: integrated learning, early childhood education, aspects of children's development 


\section{PENDAHULUAN}

Anak adalah individu yang berbeda, unik, dan memiliki karakteristik tersendiri sesuai dengan tahap perkembangannya. Pentingnya mendidik anak sejak usia dini ini dikarenakan masa anak-anak merupakan masa yang sangat peka terhadap pengaruh dari luar, dan pendidikan pada masa anak akan menjadi construk yang berpengaruh terhadap perkembangan anak selanjutnya. Anak yang distimulasi sejak dini akan tampak berbeda dengan anak yang dibiarkan berkembang tanpa adanya stimulasi di usia dini.

Menurut pendapat Morisson (1988, p.3), Pendidikan Anak Usia Dini adalah pendidikan yang diperuntukan kepada anak dari lahir sampai umur 8 tahun. "Early Childhood Education (ECE) is the education of chlidren from birth to age eight". Pada masa ini sering disebut masa keemasan (golden age), di mana stimulasi seluruh aspek perkembangan berperan penting untuk tugas perkembangan selanjutnya. Perlu disadari bahwa masa-masa awal kehidupan anak merupakan masa terpenting dalam rentang kehidupan seseorang anak. Pada masa ini pertumbuhan otak sedang mengalami perkembangan yang sangat pesat.

Pada proses pembelajaran, kurikulum yang digunakan dalam Pendidikan Anak Usia Dini bersifat unified, artinya berbagai bidang studi diramu dalam satu tema melalui pembelajaran terpadu. Sesuai dengan pendapat Roopnarine dan Johnson (2011, p.291) yang terpenting adalah bahwa apa dan bagaimana dalam pembelajaran harus saling terkait. Untuk belajar dari pengalaman, anak-anak harus terlibat secara langsung dan aktif dengan lingkungan sosial maupun fisik.

Namun pada pelaksanaannya, proses pembelajaran di Pendidikan Anak Usia Dini guru mulai meninggalkan makna dari pembelajaran terpadu tersebut. Sebagian besar guru terlalu memaksakan kegiatan pembelajaran yang lebih menekankan pada pencapaian tertentu, dan tekanan dari orang tua anak khususnya anak-anak usia 5-6 tahun yang merupakan usia persiapan untuk pendidikan ke Sekolah Dasar. Pencapaian yang diinginkan bukan lagi mengenai kemampuan anak dalam kemandirian, maupun sosialisasi namun lebih kepada kemampuan pengetahuan membaca, menulis, dan berhitung.

Sedangkan tujuan sebenarnya pembelajaran matematika untuk anak usia dini adalah belajar berfikir logis dan matematis (logico-mathematical learning) dengan cara menyenangkan dan tidak rumit. Jadi tujuannya bukan agar anak dapat menghitung sampai seratus atau seribu, tetapi memahami bahasa matematis dan penggunaannya untuk berfikir. Piaget dalam Suyanto, (2005, p.157).

Banyak orang tua lebih bangga bila anak bisa membaca pada usia 4-5 tahun (usia TK) dibandingkan menguasai kemampuan atau keterampilan hidup yang lebih diperlukan hingga dewasa nantinya. Padahal sekolah unggul adalah sekolah yang memanusiakan manusia, menghargai setiap potensi peserta didik. Chatib (2010, p.96) menyatakan bahwa, kemampuan anak untuk memecahkan masalah, berlogika, maupun tidak mudah putus asa sudah jarang sekali terlihat. Anak-anak tersebut seperti kehilangan kepribadiannya dengan mudah mengikuti sikap atau perilaku orang lain.

Masa kanak-kanak yang hanya terjadi satu kali harus benar-benar dipersiapkan agar potensi anak dapat berkembang optimal. Salah satu hal yang harus kita perhatikan adalah kapan anak belajar, agar anak usia dini tidak merasa dibebani dengan kegiatan belajar tersebut. "Children learn when time is right for learning. This is the foundation of the concept of readiness." (Morrison, 1988, p.141). Pondasi dasar bahwa anak belajar ketika waktunya tepat merupakan konsep dari kesiapan anak.

Pembelajaran pada masa anak usia dini, seharusnya bertujuan untuk mengembangkan semua aspek perkembangan anak terutama kemampuan dasarnya yang akan digunakan pada masa dewasa nantinya. Bukan dengan memberikan beban pembelajaran yang seharusnya belum dikuasai anak. Dalam proses pendidikan anak usia dini, guru harus memahami prinsip yang digunakan dalam kegiatan pembelajaran yang mengembangkan aspek perkembangan 
anak. Sesuai dengan pendapat Morrisson (1988, p.141), Proses perkembangan anak usia dini paling baik melalui cara membebaskan anak untuk berkreasi sebebasbebasnya, bukan melalui paksaan atau sengaja dibentuk.

Dari studi pendahuluan yang dilakukan oleh penulis bahwa masyarakat memberikan respon yang positif terhadap KB-TK Islam Al Azhar 31 Yogyakarta, bukan karena nama besarnya yang telah didengar tapi lebih kepada pembelajaran yang diberikan kepada anak-anak. Dengan landasan dasar Al Qur'an dan hadist sebagai pedoman pembelajaran, anak-anak juga belajar untuk melakukan segala sesuatu di kehidupan sehari-hari agar dapat mengembangkan nilai etika Islam yang pada hakikatnya mampu meningkatkan kecerdasan emosi.

Persoalannya adalah apakah pendidikan yang diselenggarakan dengan memberikan nilai tambah efektif bagi anak? Pertanyaan tersebut muncul mengingat agama merupakan hal yang abstrak, apa lagi bagi anak usia dini, perbedaan apa yang diberikan KB-TK Islam Al azhar dibandingkan dengan sekolah Islam yang lainnya.

Usia o-8 tahun masih berfikir secara konkrit. Oleh karena itu diharapkan proses pembelajaran yang dilaksanakan senyata mungkin dengan kehidupan anak. salah satu model pembelajaran yang digunakan pada pendidikan anak usia dini yaitu model pembelajaran terpadu dengan tema.

Pembelajaran terpadu sendiri merupakan suatu sistem pembelajaran yang memungkinkan anak, baik secara individual maupun kelompok, aktif mencari, menggali dan menemukan konsep serta prinsip keilmuan secara holistik, bermakna, dan otentik. Pembelajaran terpadu akan terjadi apabila peristiwa-peristiwa otentik atau eksplorasi topik/tema menjadi pengendali di dalam kegiatan pembelajaran. Dengan berpartisiasi di dalam eksplorasi tema/peristiwa tersebut anak belajar sekaligus memahami proses dan isi kegiatan pembelajaran secara serempak.

Apabila dikaitkan dengan tingkat perkembangan anak, pembelajaran terpadu merupakan pendekatan pembelajaran yang memperhatikan dan menyesuaikan pem- berian konsep sesuai tingkat perkembangan anak. Pendekatan berangkat dari teori pembelajaran yang menolak drill-system sebagai dasar pembentukan dan struktur intelektual anak. Pembelajaran dengan tema melibatkan kreativitas dalam menyusun satuan pendidikan seperti perencanaan aktivitas disekitar pokok bahasan.

Sesuai yang diungkapkan oleh Eliason and Jenkins, 1994; Machado and Meyer, 1996 (Kostelnik, 1999, p.507) tentang pengertian pembelajaran tema, "Theme teaching involves creating an array of educationally sound activities planned around a central idea. These activities are integrated into all aspect of the curriculum and take place within a concentrated time frame, ranging from several weeks. This creates children's generalization of knowledge and skills from one experience to another." Secara tidak langsung, tema membantu anak dalam proses pembelajaran secara keseluruhan.

Keuntungan dengan menggunakan model pembelajaran terpadu dengan tema sesuai dengan pendapat Kostelnik (1999, pp.508-509). Kelebihan pembelajaran tema bagi anak yaitu, memberikan kesempatan kepada setiap anak untuk mengeksplorasi semua informasi yang dibutuhkan, tema membuat anak memasuki dunia tersebut, nilai lain dari pembelajaran tema adalah menjaga agar kurikulum anak usia dini tetap bervariasi dan menarik, kelompok keterpaduan memberikan kesempatan kepada beberapa anak untuk fokus pada faktafakta tertentu secara bersama-sama, serta merubah ketertarikan anak dengan menyesuaikan usia.

Dalam pembelajaran terpadu menggunakan tema, akan fokus pada isi tema. Isi pembelajaran menggunakan tema meliputi kesemua informasi yang mengandung relevansi dengan tema. Isi pembelajaran dibutuhkan kemampuan seperti mengikuti, mendengarkan, mengamati, mengingat, dan menceritakan kembali. Tema yang paling bagus adalah tema yang yang memiliki kegiatan potensial serta anak dapat melakukan pengalaman pertamanya melalui kegiatan tersebut.

Sedangkan ketentuan jumlah tema yang dibahas tidak dapat berbeda-beda, hal 
tersebut sesuai dengan hasil penelitian Archana V. Hegde dan Deborah J.Cassidy 2009, tentang Kindergaten Teachers' Perspective on Developmentally Appropriate Practice (DAP): A Studi Conducted in Mumbay (India), "Hasil dari penelitian kualitatif ini mengemukakan bahwa ada 6 tema yang digunakan dalam proses pembelajaran. Oleh karena itu banyak sedikitnya tema ditentukan oleh bagaimana keadaan anak dan kondisi sekolah. Berikut ini contoh tema yang dapat digunakan dalam proses pembelajaran terpadu dengan tema "Cats",

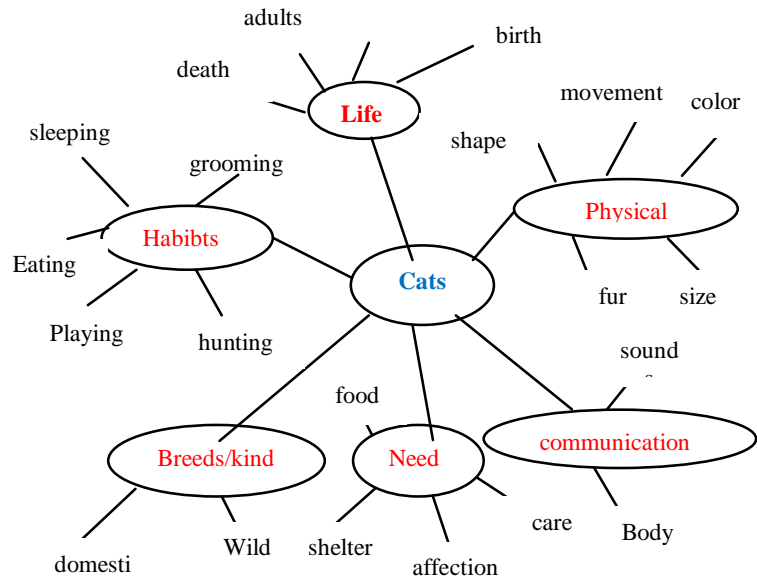

Gambar 1. Tema dengan Model Webbing Initial Topic Web for "Cats" Theme

Dengan tema "Kucing" dalam satu hari anak akan diajak untuk mengetahui lebih dalam mengenai kucing mulai dari apa yang dibutuhkan kucing, bagaimana kucing berkomunikasi, karakter fisik kucing, kelakuan kucing, jenis kucing, dan siklus hidup kucing.

Dalam Integrating Curricullum Through Theme Teaching bentuk keterkaitan topik menggunakan model Webbing. Tahapan yang dilakukan dalam pembelajaran yang menggunakan dengan pembelajaran terpadu melalui tema model Webbing antara lain: "Select a theme, Use reference books, As the list grows, Decide the sub topic, Cek your plans, Brainstorm activities, Assign each activities, Make sure the activities represent, Commit your idea, Check your plan, Explore your plan with children, Adjust your plan, Plan a portion of group time to focus on the theme each day, Make a final check, Create any props, Create thematic atmosphere, Carry out your plan, Assess children's understanding of and interest in the theme, Help the children reflection, Extend the theme, Talk the children about what they want to know more, Establish two way communication with families about the theme, Evaluation your implementation. Helm Harris Judy (Kostelnik, 1999, pp.517-522). Tahapan yang dilakukan meliputi perencanaan, pelaksanaan, dan evaluasi.

Pendidik memiliki tanggung jawab memberikan pembelajaran sesuai dengan yang dibutuhkan anak baik secara fisik maupun nonfisik. Secara fisik berupa gedung, kelas, dan arena permainan yang aman dan melatih anak untuk menggunakan peralatan dan perlengkapan yang aman. Anak sebagai individu yang unik memiliki karakteristik yang berbeda, dibutuhkan stimulasi yang sesuai dengan kebutuhannya. Dengan pembelajaran terpadu yang digunakan dalam lembaga PAUD diharapkan perkembangan anak akan lebih maksimal.

Setiap anak memiliki perkembangan dan pertumbuhan yang khas, dia bisa berbeda sifat, berbeda kecederungan serta kecepatannya antara satu anak dengan anak lainya, berbeda kecederungan serta kecepatanya antara satu anak dengan anak lainya. Menurut Montessori (Roopnarie dan Johnson, 2009, pp.384-385) ...pendidikan sebagai sarana "memberikan bantuan pada kehidupan anak, ...membantu proses perkembangan pikiran". Perkembangan anak akan selalu mengikuti proses pendidikan, dan proses pendidikan akan berfungsi sebagai cara agar perkembangan bisa lebih optimal.

Hurlock (1990, p.23), mengungkapkan bahwa perkembangan anak-anak pada umur tertentu meliputi aspek-aspek (1) pertumbuhan fisik, (2) perkembangan motorik, (3) perkembangan bicara, (4) perkembangan emosi, (5) perkembangan sosial, (6) perkembangan bermain, (7) perkembangan kreativitas, (8) perkembangan pengertian, (9) perkembangan moral, (10) peran seks, dan (11) perkembangan kepribadian. Orientasi pendidikan pada anak usia dini tidak hanya terbatas pada aspek pengembangan kecerdasan (IQ) semata tetapi juga menca- 
kup aspek-aspek perkembangan yang lebih luas meliputi aspek kognitif, motorik, sosialemosional-spiritual, dan bahasa.

\section{Aspek Kognitif}

Aspek Perkembangan kognitif pada anak, menggambarkan bagaimana pemikiran berkembang dan berfungsi sehingga dapat berfikir. Santrock (1997, p.121), mengatakan bahwa dunia kognisi anak pra sekolah merupakan sesuatu yang kreatif, bebas dan menyenangkan, pada masa itu imajinasi anak tentang dunia berkembang sangat pesat.

Piaget (Goswani, 2011, p.652) membagi tahap perkembangan anak menjadi empat tahap yaitu, masa sensorik dari lahir hingga usia 2 tahun, masa praoperasional usia 2 sampai 7 tahun, masa operasional kongkret dari usia 7 sampai 11 tahun, dan masa operasional formal antara usia 11-15 tahun.

Pada tahap sensorimotor, anak lebih banyak menggunakan gerak refleks dan indranya untuk berinteraksi dengan lingkungannya. Dalam tahap ini terdapat tahap: (1) reflexive stage, (2) Primary circular Action, (3) secondary circular reaction, dan (4) coordination of secondary schemata. Pada tahap perkembangan preoperational, menurut pendapat Piaget (Morrisson, 1988, p.107) anak yang berkembang adalah anak yang aktif. Hal itu dikarenakan kemampuan anak untuk melakukan sesuatu merupakan refleksi terhadap psikologis dan mentalnya. Oleh karena itu sebagai guru harus bisa memahami anak dengan menyediakan berbagai aktivitas dan kesempatan untuk mengekpresikan hal-hal baru. Setiap kegiatan yang dilakukan oleh anak memberikan kontribusi terhadap perkembangan intelektualnya.

Di masa praoperasional tahap berfikir anak masih menggunakan simbol atau lebih dikenal dengan benda-benda yang kongkrit sehingga anak akan lebih mudah memahami sesuatu bila diperlihatkan secara langsung. Dengan simbol anak mampu merepresentasikan berbagai hal yaitu, bahasa yang dapat digunakan untuk mendukung dan membantu perkembangan anak, pekerjaan seni dengan berbagai bentuk kegiatan juga dapat membantu anak untuk merepresen- tasikan keinginan dan idenya, dan pendekatan dengan pengalaman bahasa membantu anak dalam mengekspresikan keinginannya

\section{Sosial Emosional}

Kemampuan Sosial anak dan gayanya sangat berbeda-beda satu dengan yang lain. Dengan perbedaan tersebut, sebagai pendidik yang menjadi bagian dari kehidupan anak akan memperoleh pengalaman yang berbeda sesuai dengan karakter anak. Anak yang tidak mampu menguasai kemampuan sosial ketika masih berusia o-8 tahun memiliki resiko ketidakmampuan untuk beradaptasi. (Nissen \& Hawkins, 2008, p.21).

Kegiatan bermain merupakan adalah kegiatan yang dilakukan oleh anak sebagai simbol dimulai kontak sosial. Pola yang ditimbulkan oleh anak dalam kontak sosial berupa pola perilaku sosial dan pola tidak sosial. Sesuai dengan yang dikemukakan oleh Hurlock (1980, p.118) sebagai berikut:

\section{Perilaku Sosial}

Dalam pola perilaku sosial, anak akan memunculkan pola meniru, persaingan, kerja sama, simpati, empati, dukungan sosial, membagi, dan perilaku akrab.

\section{Perilaku tidak Sosial}

Sedangkan dalam perilaku tidak sosial anak terlihat sikap negativism, agresif, perilaku berkuasa, memikirkan diri sendiri, mementingkan diri sendiri, dan merusak.

\section{Perkembangan Bahasa}

Dalam perkembangan bahasa yang dialami oleh anak usia dini tidak hanya terjadi ketika anak sudah lahir dan mendengar dari lingkungan sekitar. Seperti yang dikemukakan oleh Saxton, (2010, p.109), "...language learning begins before the baby is even born". Anak mulai dapat mendengar suara sebelum lahir. Diusia kehamilan pada minggu ke 16 dimana telah ditiupkan roh kehidupan, dari sejak itu anak mulai memberikan respon ketika janin diajak berbicara.

Sejak dalam kandungan anak sudah mengenal bahasa, sehingga menangis merupakan ekspresi bahasa yang reflek dilakukan 
anak ketika baru lahir. Tahapan bahasa anak dapat dilihat pada tabel di bawah ini:

Tabel 1. Language Development in Infant

\begin{tabular}{|c|c|c|}
\hline Age & Receptive & Expressive \\
\hline Birth & Startle reflex & Crying \\
\hline$\frac{1}{2}$ months & & Sosial Smile \\
\hline $\begin{array}{l}3 \text { months } \\
4 \text { months }\end{array}$ & Orients to voice & Cooing \\
\hline $\begin{array}{l}5 \text { months } \\
6 \text { months }\end{array}$ & Orients to bell (look to side) & $\begin{array}{c}\text { “Ah-goo" Razzing } \\
\text { Babbling }\end{array}$ \\
\hline 7 months & Orients to bell (look to side, then up) & $\begin{array}{l}\text { "Da-da" and "Ma-ma" (used } \\
\text { inappropriatly) }\end{array}$ \\
\hline $\begin{array}{l}8 \text { months } \\
9 \text { months }\end{array}$ & Gesture & $\begin{array}{l}\text { "Da-da" and "Ma-ma" (used } \\
\text { inappropriatly) }\end{array}$ \\
\hline 10 months & $\begin{array}{c}\text { Orients to bell (turn directly toward } \\
\text { bell) }\end{array}$ & \\
\hline $\begin{array}{l}11 \text { months } \\
12 \text { months }\end{array}$ & One step command (with gesture) & $\begin{array}{l}\text { One word } \\
\text { Two words }\end{array}$ \\
\hline
\end{tabular}

Sumber: Arnold J. Capture and Pasquale J. Accardo (Morrisson,1988, p.63)

Perilaku sosial yang ditunjukkan oleh anak dipengaruhi oleh berbagai hal, salah satunya adalah jenis kelamin. Anak usia dini baik laki-laki ataupun perempuan dapat dengan mudah membedakan jenis kelamin meskipun telah berganti baju dan memotong rambut. Namun perbedaan jenis kelamin mempengaruhi perilaku anak, sependapat dengan yang dikemukakan oleh Pasterski dkk (Smith and Hart, 2011, p.281) yaitu: pada usia dini sekitar usia 3-7 tahun perilaku sosial dipengaruhi oleh jenis kelamin, permainan yang tersedia, teman sepermainan, dan gaya bermain anak.

Perkembangan bahasa anak akan semakin berkembang bila guru mampu memberikan stimulasi yang sesuai dengan tahap perkembangannya. Hal tersebut diperkuat oleh hasil penelitian mengenai perkembangan bahasa anak dengan stimulasi kegiatan story telling dan Language Development Scale yang di lakukan oleh Marjanovic, dkk (2006, p.48) "children who entered preschool at an early age showed higher storytelling competence than those who entered preschool at 3 years of age on both meansurements." Pada usia 2 tahun anak yang distimulus dengan kegiatan story telling, perkembangan bahasanya melebihi anak yang masuk sekolah pada usia 3 tahun.

\section{Perkembangan Fisik}

Aspek perkembangan secara fisik anak terlihat dengan jelas sekali perkembangannya. Yang paling terlihat sangat signifikan adalah perkembangan otak anak, pada usia 2 tahun perkembangan otak anak sebesar 80\% sedangkan ketika sudah dewasa perkembangan otaknya sekitar seperempat dari keseluruhan ukurannya. "The brain, for example is only one fourth (23 percent) its adult size at birth, but it develops to about 80 percent of its adult size by age two." (Morisson, 1988, p.36)

Sedangkan pertumbuhan secara fisik anak baik tinggi dan berat dipengaruhi akan perbedaan jenis kelamin, latar belakang genetik, dan faktor lingkungan. Selain itu pengasuhan yang baik dan kemampuan mengasuh anak serta kebiasaan juga mempengaruhi perkembangan fisik anak. "Height and weight depend on sex, genetic background, and environmental factors.... Good parenting and child-care-skills and habits also contributing factors." (Morisson, 1988, p.36)

Perkembangan motorik anak tidak hanya berupa gerakan menandang, melompat, atau berlari. Sejak anak berumur o bulan, perkembangan motoriknya sudah mulai berkembang. Gerakan yang dilakukan masih sebatas gerakan refleks seperti meng- 
hisap puting susu ibunya dan menghisap air susu. Seperti yang diungkapkan oleh Saxton (2010, p.17) yaitu, "at age o months developing milestone in the first five years in perceptual-motor: reflexes (e.g. grasping, sucking)".

Perkembangan motorik anak terbagi menjadi dua yaitu, perkembangan motorik kasar dan motorik halus. Kegiatan motorik kasar, merupakan aktivitas anak yang menggunakan otot besarnya. Motorik kasar adalah aktivitas yang berhubungan dengan aktivitas yang menggunakan seluruh anggota tubuh seperti merangkak, merayap, berjalan, memanjat, melompat, meloncat, melompati dan melempar.

Sedangkan motorik halus aktivitasnya melibatkan otot yang lebih kecil pada tubuh. Beberapa aktivitas motorik halus berhubungan dengan tangan dan jari. Aktivitas yang dilakukan meliputi, menyerap, mengeluarkan, memindahkan, menandai, mencoret-coret, dan menulis.

\section{METODE}

\section{Jenis}

Penelitian ini merupakan penelitian kualitatif dengan pendekatan fenomenologis naturalistik. Pendekatan fenomenologis naturalistik dalam penelitian, bermakna memahami peristiwa dalam kaitannya dengan orang dalam situasi tertentu.

\section{Waktu dan Tempat}

Penelitian ini dilaksanakan di KB - TK Islam Al Azhar 31 Yogyakarta, dengan sasaran pendidikan anak usia 3-6 tahun. Pertimbangan pemilihan KB-TK Islam Al Azhar ${ }^{1}$ Yogyakarta sebagai tempat penelitian, selain didasarkan karena alasan waktu dan sumber yang tersedia, juga didasarkan pada keunikan yang menyediakan proses pembelajaran berdasarkan pada kegiatan dikehidupan sehari-hari dengan tujuan dapat mengembangkan nilai etika Islam. Waktu penelitian dilakukan selama 4 bulan terhitung sejak bulan Maret sampai dengan bulan Juni 2012.

\section{Subjek}

Dalam penelitian ini yang dijadikan subjek penelitian adalah semua komponen yang terlibat dalam kegiatan pendidikan anak usia dini di KB - TK Islam Al Azhar 31 Yogyakarta, baik penyelenggara, pendidik, orang tua, dan anak.

\section{Teknik Pengumpulan Data}

Pengumpulan data dalam penelitian ini dilakukan dalam tiga tahap. Pada tahap pertama, dilakukan mengumpulkan data secara umum dan luas tentang hal-hal yang menonjol, menarik, penting serta berguna untuk diteliti lebih mendalam. Tahap kedua, eksplorasi pengumpulan data yang dilakukan lebih terarah sesuai dengan fokus penelitian serta mengetahui sumber data atau informan yang kompeten dan mempunyai pengetahuan yang cukup banyak tentang hal yang akan diteliti. Tahap ketiga peneliti melakukan penelitian terfokus yaitu mengembangkan penelitian eksploratif kepada fokus penelitian yaitu pada masalah implementasi pembelajaran terpadu pada pendidikan anak usia dini di KB-TK Islam $\mathrm{Al}$ Azhar 31 Yogyakarta.

Data yang dikumpulkan berdasarkan pada kegiatan:

\section{Pengamatan}

Dalam penelitian ini tehnik pengamatan digunakan untuk, mengamati, mengumpulkan data dan mendeskripsikan tentang aktivitas pendidik, aktivitas anak, suasana belajar dan bermain, lingkungan belajar, dan sarana bermain.

\section{Wawancara}

Wawancara untuk menggali informasi dari penyelenggara dan pendidik meliputi pertanyaan tentang, motivasi mendirikan, harapan terhadap anak, usaha yang dilakukan untuk meningkatkan kualitas pembelajaran di KB-TK Islam Al Azhar 31 Yogyakarta.

\section{Dokumentasi}

Dokumen-dokumen yang dipelajari meliputi: (1) data mengenai kelembagaan, data penyelenggara, data pendidik, data anak, (2) Data mengenai proses pendidikan seperti rencana program belajar, lembar penilaian, hasil karya anak dan foto-foto kegiatan. 


\section{Keabsahaan Data}

Pemeriksaan keabsahan data pada penelitian ini mengikuti kriteria yang diajukan oleh Nasution (1992) dan Moleong (1993) yaitu derajat kepercayaan (credibility), keteralihan (transferability), kebergantungan (dependability) dan kepastian (confirmability).

\section{Analisis Data}

Analisis data pada model ini terdiri dari 4 komponen yang saling berinteraksi yaitu: pengumpulan data, reduksi data, penyajian data, dan penarikan kesimpulan dan verifikasi. Keempat komponen itu merupakan siklus yang berlangsung secara terus menerus antara pengumpulan data reduksi data, penyajian data dan penarikan kesimpulan dan verifikasi data.

\section{HASIL DAN PEMBAHASAN}

\section{Deskripsi Hasil}

Implementasi Pembelajaran Terpadu

\section{Perencanaan Pembelajaran}

Kurikulum yang digunakan oleh KBTK Islam AL Azhar 31 Yogyakarta disusun berdasarakan Permen Diknas No. 58 tahun 2009 digabungkan dengan kurikulum dari sekolah Al azhar. Dalam pelaksanaan perencanaan kurikulum yang dilakukan di KB-TK Islam Al Azhar 31 Yogyakarta terlebih dahulu mengambil kompetensi dasar dari laporan perkembangan hasil belajar. Mencari indikator di KPPM atau di Standar isi Permen Diknas no.58 tahun 2009. Menurunkan kedalam rencana semester, triwulan atau term dan mingguan. Membuat rekapitulasi penilaian yang berasal dari rencana triwulan atau "term".

Dari pencapaian term selanjutnya menentukan tema yang akan dibahas, baru ditentukan Rencana Kegiatan Mingguan yang berisi kegiatan pembelajaran bukan lagi indikator pencapaian. Selanjutnya disusun dalam bentuk jaring tema "Spider web" dengan menyesuaikan tema yang diangkat dalam satu minggu tersebut, baru disusun Rencana Kegiatan Harian yang mencakup kegiatan selama sehari sampai dengan evaluasi yang dilakukan serta tindak lanjut yang akan direncanakan.

Selain kegiatan pembelajaran secara terstruktur, pembelajaran yang tidak terstruktur juga direncanakan diawal tahun dalam kegiatan rapat kerja. Kegiatan yang direncanakan antara lain, puncak tema, proses, sains dan AVA yang disesuaikan dengan tema dan tingkatan kelas anak. sedangkan perencanaan kegiatan tahunan meliputi peringatan hari besar keagamaan ataupun hari besar nasional.

\section{Pelaksanaan Pembelajaran}

Proses pembelajaran yang dilaksanakan meliputi kegiatan pembukaan, inti, dan penutup. Dalam setiap kegiatan pembelajaran di Kelas Toddler, kelompok Bermain, dan TK membahas 4 tema setiap tahun ajaran.

Kegiatan Pembukaan dimulai dari ikrar yang dilakukan di halaman sekolah dilanjutkan kegiatan morning meeting di dalam kelas. Kegiatan morning meeting meliputi greeting dan sharing. Selain itu anak membaca doa sehari-hari dan surat pendek, sedangkan dihari Jumat anak akan melakukan kegiatan berwudhu dan sholat berjamaah.

Selanjutnya kegiatan inti dimulai dengan kegiatan penjelasan tema secara klasikal. Kegiatan didalam kelas dilakukan dengan moving area, pendidik akan memberikan kesempatan kepada setiap anak untuk memilih setiap area terlebih dahulu. Anak boleh berpindah area setelah menyelesaikan tugas diarea sebelumnya. Kegiatan inti diakhiri dengan makan bersama-sama.

Pada waktu tertentu seperti puncak tema, kegiatan pembelajaran akan menyesuaikan dengan kegiatan yang akan dilakukan. Misalnya puncak tema hewan, kegiatan pembelajran dalam satu hari dilakukan di pasar hewan Bantul "Pasthi". Sehingga anak mendapatkan penjelasan secara langsung sub tema yang telah dibahas selama 1 term. Begitu juga dengan kegiatan AVA, melihat film atau video menyesuaikan dengan tema dan dilakukan diantara kegiatan pembelajaran yang lain. 


\section{Evaluasi Pembelajaran}

Kegiatan evaluasi yang dilakukan di KB-TK Islam AL azhar 31 Yogyakarta, sama dengan lembaga-lembaga pendidikan anak usia dini pada umumnya menggunakan hasil penilaian dengan bentuk narasi (cerita) dengan kriteria penilaian BT (Belum Tampak); MB (Mulai Berkembang); BSH (Berkembang Sesuai Harapan); dan BSB (Berkembang Sangat Baik). Metode yang digunakan yaitu: (a) metode observasi, (b) metode percakapan, (c) metode porto folio, (d) metode unjuk kerja, (e) metode hasil karya.

Metode penilaian observasi, percakapan, unjuk kerja, dan hasil karya digunakan di setiap kegiatan pembelajaran. yang nantinya akan hasil penilaian akan dimasukkan kedalam rekpitulasi penilaian untuk menentukan nilai pada buku laporan perkembangan setiap term. Untuk penilaian porto folio dilakukan sekali setiap term dengan bidang pengembangan yang berbeda-beda. Penilain ini juga berbeda dengan hasil karya yang telah dihasilkan anak setiap hari.

Kriteria penilaian yang diberikan kepada anak pada hasil karya dengan memberikan tanda bintang mulai dari satu bintang hingga empat bintang. Dan hasil penilaian akan langsung masuk kedalam rekapitulasi nilai anak. Demikian juga dengan metode penilain yang lain seperti unjuk kerja yang sering dilakukan di pagi hari ketiak kegiatan morning meeting, dan penilaian observasi lebih banyak digunakan untuk menilai kegiatan yang mengembangkan sosial emosional anak dan motorik kasarnya.

Proses keterpaduan yang dilaksanakan pada proses pembelajaran terpadu dengan agama sebagai pusatnya masih dengan pembiasaan dan belum memberikan kebermaknaan. Agama adalah hal yang masih abstrak bagi anak usia dini oleh karena itu proses pembelajaran dengan pembiasaan tidak akan memberikan pengaruh apapun terhadap anak. Sebagaimana pendapat Piaget (Morrison, 1988, p.113) mengenai tahapan berfikir anak agar proses pembelajaran yang masih abstrak bisa diterima, dengan memberikan alasan "reason" atau tujuan "purpose".
Proses pembelajaran agama akan lebih bermakna pada anak bila anak dapat melihat secara langsung alasan atau tujuan mempelajari agama. Sebagai contohnya mengucap salam tidak hanya dibiasakan di setiap pagi namun berikan alasan kenapa anak harus mengucap salam sehingga anak dapat berfikir bahwa mengucap salam memiliki tujuan bukan pembiasaan. Proses pembelajaran harus lebih menekankan pada pemahaman anak terhadap kegiatan ibadah yang dilakukan, sehingga ketika dewasa nantinya anak memiliki kesadaran sendiri untuk melaksanakan ibadah tersebut meskipun tidak dilihat atau dinilai oleh guru dan orang tua.

Kurikulum memang bukan satusatunya hal yang menentukan dalam tujuan pembelajaran, namun memberikan ramburambu terhadap penggunanya agar tidak keluar dari ranah yang telah ditentukan. Dengan mengetahui hal yang harus dilakukan untuk mendukung proses pembelajaran, sebaiknya sebuah kurikulum menekankan pada hal-hal yang sangat penting dan jelas dengan memberikan bekal yang akan digunakan anak untuk menghadapi tantangan di masa depan, sesuai dengan hasil penelitian dari Stig Brostrom, (2006, p.65), "... a curriculum emphasing a critical content, which in a much more emphatic way gives the future generation a chance to cope with future challenges. Pembelajaran pada usia dini sebaiknya menekankan pada keterampilan yang akan digunakan sampai anak dewasa nantinya, seperti yang kita ketahui diusia golden age merupakan saat yang tepat untuk memberikan segala hal yang akan bermanfaat karena masa ini tidak akan terulang kedua kalinya.

Dalam tahap perencanaan pembelajaran, alur perencanaan yang dilakukan sebaiknya sistematis dimulai dari penentuan TPP (Tingkat Pencapaian Perkembangan), di uraikan dalam indikator dan kegiatan pembelajaran, kemudian mengkaitkan kegiatan pembelajaran yang sesuai. Apabila dalam tahap perencanaan tidak dilakukan sebagaimana mestinya maka proses selanjutnya akan terjadi ketimpangan dalam pelaksanaan maupun evaluasi pembelajaran. hal tersebut sesuai dengan yang dikemu- 
kakan oleh Worthen and Sanders, (1973, p.40) "planning is essential in systematic evaluation studies. Without rigorous outline, evaluation studies can easily proceed without direction, and hence, without any end point."

Proses pembelajaran yang terpadu yang dilaksanakan belum mengaitkan kegiatan pembelajaran ke dalam aspek perkembangan karena dalam proses perencanaan yang dilakukan belum sesuai dengan sistematika yang seharusnya dilakukan. Kegiatan pembelajaran masih terpisah dengan aspek perkembangan yang ingin dikembangkan oleh pendidik.

Pembelajaran dengan setting area di dalam kelas pendidikan anak usia dini, terbukti lebih sesuai dan tempat yang responsif untuk bertemunya kebutuhan anak usia dini. Area mengikuti aktivitas dan tujuan dibangunnya lingkungan belajar oleh orang dewasa sesuai dengan instruksi untuk mengembangkan perkembangan akan keterampilan yang utama dan kemampuan pada anak. Tujuan menggunakan area diharapkan mampu menyatukan tema yang dibahas salam satu hari tersebut tidak terpisah satu dengan yang lain mengingat cara anak usia dini yang masih berfikir secara holistic atau menyeluruh. Namun dalam proses pembelajarannya area masih mengikat kegiatan anak, kegiatan di area masih menyesuaikan dengan nama area tersebut.

Hal tersebut dikaji dari pendapat Kostelnik, (1999, p.157), yang menyatakan tentang karateristik dalam pembelajaran anak usia dini dengan area yang efektif. ..."Center-based activity can be much more successful when teachers take time to introduce children encounter them." Area yang ada di kelas juga tidak terpaku sesuai dengan namanya saja, "...could be used to address the cognitive domain one day, the language domain another day, and the social domain on yet another". Diharapkan guru pendidikan anak usia dini mampu lebih kreatif dalam memanfaatkan area yang telah tersedia, menggunakan berbagai permainan yang telah ada didalamnya tanpa harus terpaku memberikan lembar kerja atau tugas kepada anak yang tidak sesuai dengan tema yang dibahas bersama.
Sedangkan pada proses evaluasi Dalam kegiatan penilaian tersebut belum digunakan rubrik penilaian sehingga proses evaluasi belum objektif. Oleh karena itu penilaian yang diberikan belum bisa mewakili hasil perkembangan anak selama proses pembelajaran. Sebagaimana pendapat dari Kostelnik, (1999, p.547), mengenai bentuk penilaian dengan menggunakan tema metode yang digunakan antara lain "Anecdotal record, Frequency counts and charts, Checklist, Rating scales, Participation chart".

Hal tersebut diperkuat oleh hasil penelitian dari Hannah Nissen dan Carol J. Hawkins "Observasing and Supporting Young Chlidren's Social Competence“, yang mengemukakan metode penilaian yang dilakukan pada proses pembelajaran anak usia dini khususnya aspek perkembangan sosial yaitu Anecdotal record, Anecdotal record, dan video. Dengan bentuk penilaian yang menekankan pada aspek perkembangan dan pembelajaran anak, berdasar pada peristiwa nyata, penampilan anak, berhubungan dengan instruksi, fokus pada tujuan pembelajaran, melibatkan semua konteks pembelajaran, gambaran umum akan kemampuan belajar anak, dan bentuk kolaborasi lingkungan anak akan terlihat perkembangan anak yang lebih jelas.

Bentuk penilaian yang diberikan kepada anak sama dengan lembaga pendidikan anak usia dini yang lain menggunakan narasi namun dalam menilai belum tersedia pedoman instrument penilaian. Nilai yang diberikan belum memperlihatkan objektivitas, sehingga setiap kriteria nilai anak akan berbeda-beda.

\section{Pengaruh Pembelajaran Terpadu}

\section{Perkembangan Kognitif}

Pada aspek perkembangan kognitif anak di KB-TK Islam Al Azhar 31 Yogyakarta sebagaimana teori Piaget (Morisson, 1988, p.21) anak memasuki masa preoperational, perkembangan kogntif yang paling menonjol adalah egosentris. Ego sentrisme, yaitu anak memandang dunia luar dari sudut pandang subjeknya, sikap ini terlihat dominan dialami oleh anak usia Kelompok Bermain. 
Apabila perkembangan kognitif yang dialami oleh anak, dikaji dari pendapat John Piaget (Morrison,1976, p.105), anak usia dini 2-7 tahun memasuki tahap berfikir secara "preoperational" egosentris memang hal yang biasa dialami oleh anak usia 3 tahun dan akan berkurang bila memasuki usia 4 tahun. Namun sebagai pendidik, tetap memiliki kewajiban untuk mengembangkan kemampuan anak agar egosentrisnya dapat berkembang lebih maksimal.

Pada masa preoperasional sebagaimana teori John iaget dalam (Morrison, 1988, p.105) anak belum mampu membedakan massa, kualitas, dan volum bila ditempatkan pada tempat, ukuran, serta dimensi yang berbeda. Proses pembelajaran yang lebih maksimal akan diperoleh hasilnya bila anak mengenal melalui hal nyata dan kegiatan yang dilakukan dengan suasana menyenangkan. Dengan proses pembelajaran yang telah berlangsung, perkembangan kognitif yang telah dicapai anak antara lain pengenalan warna, konsep bilangan, simbol, posisi, dan waktu. Kegiatan yang dilakukan untuk mengembangkan kemampuan anak, terkait dengan pengenalan konsep simbol, bilangan, warna, posisi, dan waktu lebih banyak dilakukan dengan mengerjakan lembar kerja atau worksheet dan sharing.

Kegiatan sharing adalah kegiatan yang dilakukan untuk perkembangan anak agar egosentris berkurang. Anak mulai diminta untuk menceritakan kegiatannya di hari libur atau kegiatan dirumah didepan temantemannya. Setelah anak selesai bercerita, pendidik akan memandu anak untuk mengungkapkan cerita dari sudut pandang yang berbeda dengan pertanyaan. Teman-temannya juga diberikan kesempatan untuk bertanya kepada anak yang bercerita, sehingga anak akan belajar untuk melihat sudut pandang cerita dari pendidik dan teman sebayamya.

Perkembangan anak di aspek kognitif akan lebih berkembang bila anak juga diajak untuk mengenal simbol-simbol, mulai dari hal yang paling sederhana di sekitar anak. selain itu hasil karya anak tidak hanya berhenti setelah anak selesai mengerjakan, pendidik bisa meminta anak untuk menceritakan apa yang telah digambar atau dibuat didepan kelas. Sehingga anak akan belajar untuk memahami sesuatu dari sudut pandang yang berbeda. Dengan pertanyaan yang akan menstimulus anak untuk menemukan konsep akan sesuatu lebih mendalam.

\section{Perkembangan Sosial Emosional}

Perkembangan sosial emosional anak sebagaimana pendapat dari Erik H. Erikson (Morisson, 1988, p.7) pada usia 2-6 tahun anak memasuki tahap Initiative vs guilt. Di masa ini, anak lebih banyak ingin mencoba hal baru dalam segala akititas. Dengan mencoba hal baru anak ingin menjadi pribadi yang mandiri dan dapat mengontrol tingkah lakunya. Bentuk perubahan yang terjadi pada anak di bidang pengembangan sosial emosional yaitu, belajar ke kamar mandi sendiri, antri masuk kelas atau kamar mandi, setiap hari selalu ada anak yang berbagi makanan kecil setelah kegiatan makan bersama di kelas dan mau berbagi mainan dengan teman. Dalam proses mengembangkan aspek sosial emosional anak akan belajar mengenai "rewards and punishment".

Pengenalan "rewards and punishment" dilakukan sejak anak masuk pertama kali, dengan memberikan hadiah kepada anak yang mau sekolah tanpa ditemani oleh orang tua ataupun walinya. Rewards yang diberikan berupa pujian "anak hebat", tanda bintang di tangan atau di rekap bintang, dan kesempatan bermain. sedangkan materi berupa mainan, alat tulis, stiker, atau asessories. Di dalam kelas "rewards and punishment" berjalan efektif, anak mampu memahami kenapa mereka memperoleh bintang atau memperoleh hukuman meskipun harus diulang berulang-ulang.

Pembelajaran dengan "rewards and punishment" selalu dikomunikasikan kepada orang tua setiap saat tidak harus menunggu waktu pembagian laporan hasil perkembangan sehingga apa yang terjadi pada anak terutama mengenai perkembangan sosial emosional lebih mudah untuk diketahui tindak lanjutnya baik di kelas ataupun di rumah. Sebagaimana pendapat Erik $H$. Erikson (Morisson, 1988, p.117), mengenai pemberian punishment kepada anak ketika melakukan tindakan tidak bertanggung 
jawab sehingga memunculkan perasaan bersalah. Dibutuhkan konsistensi, kontinuitas, dan adil dalam menerapkan pembelajaran "rewards and punishment".

Ketika di kelas anak mengalami sesuatu, misal berebut mainan dengan teman sampai menangis, anak diberikan punishment dengan meminta anak untuk minta maaf, disiang hari sewaktu dijemput guru akan memberikan laporan terkait dengan kejadian yang telah terjadi sehingga orang tua bisa mencoba untuk melakukan hal yang sama dengan di rumah.

Demikian juga untuk kegiatan toilet training, merupakan salah satu kegiatan yang ditekankan di kelas Kelompok Bermain. Dari sejak awal pendidik dan dan orang tua telah bersepakat untuk melatih anak untuk tidak menggunakan pampers. Anak akan terbiasa menggunakan kamar mandi untuk kegiatan toilet training bahkan sampai memakai celana atau rok dengan sendiri. Namun di kelas lebih atas masih ada anak yang dibantu untuk melakukan toilet training dan memakai celana atau rok. Sehingga dibutuhkan kontiunitas akan kegiatan toilet training.

Dengan prinsip konsistensi, kontinuitas, dan adil dalam proses pembelajaran yang dilakukan antara pembelajaran di sekolah dan di rumah, maka perkembangan anak akan lebih maksimal.

Perkembangan Bahasa

Perkembangan bahasa yang dijabarkan di KB-TK Islam Al Azhar 31 Yogyakarta terbagi akan 3 cakupan yaitu pengungkapan bahasa, penerimaan bahasa, dan munculnya keaksaraan. Secara garis besar kemampuan anak di bidang bahasa kegiatan pembelajaran lebih banyak di lakukan pada aspek munculnya keaksaraan. Kegiatan mengenal huruf diberikan porsi yang lebih besar dibandingkan dengan perkembangan bahasa yang lainnya. seperti kegiatan bermain peran menjadi kegiatan yang dilakukan lebih intensif pada akhir tahun untuk acara operet di tutup tahun.

Kegiatan pembelajaran dalam mengembangkan perkembangan bahasa anak, dapat dilakukan dengan berbagai metode agar anak menemukan sendiri pengalaman- nya. Metode yang sesuai dengan usia perkembangan anak usia dini antara lain, bermain drama dan story telling. Dalam kegiatan bermain drama bila dikaji menurut Morrisson, (1988, p.16o), dengan bermain drama memberikan anak kesempatan, kebebasan, dan kestabilan emosi anak untuk mencoba aturan dan kemampuan yang baru dan mengekpresikan perasaan yang dialami anak baik positif maupun negatif untuk mengembangkan kemampuan bahasa anak.

Namun di KB-TK Islam Al Azhar 31 Yogyakarta, kegiatan bermain drama memang sering dilakukan khususnya anak perempuan tetapi guru tidak memberikan petunjuk baik mengenai aturan permainan, tema, maupun cara bermain. Kegiatan bermain drama dilakukan sebagai bentuk reward bagi anak bila selesai mengerjakan lembar kerja.

Perkembangan bahasa anak akan lebih Berkembang bila guru mampu memberikan stimulus yang membuat anak menikmati kegiatan pembelajaran seperti, kegiatan story telling. Sebagaimana hasil penelitian UMEK Ljubica Marjanovic, dkk (2006, p.46) "Children who entered preschool at an early age showed higher story telling competence than those who entered preschool at 3 years of age on both measurement, although the differences were not significant". Bercerita merupakan metode yang paling efektif untuk mengenalkan bahasa pada anak karena dengan bercerita anak juga mempelajari cara mengucapkannya. Tetapi di KB-TK Islam Al Azhar 31 Yogyakarta, kegiatan bercerita hanya dilakukan untuk menunggu anak menyelesaikan kegiatan makan bersama.

Perkembangan bahasa akan berjalan lurus dengan perkembangan kognitif anak, oleh karena itu dalam mengembangkan aspek perkembangan bahasa pada anak sebaiknya tidak hanya terfokus pada kemampuan anak dalam mengenal huruf dengan kegiatan membaca atau menulis. Berikan kegiatan pembelajaran yang membuat anak aktif menemukan pengalamannya sendiri. 
Perkembangan Motorik

Dari berbagai aspek perkembangan yang sedang Berkembang dengan pesatnya pada usia dini, perkembangan yang sangat mudah diamati ialah perkembangan motorik yang terbagi menjadi motorik halus dan motorik kasar.

Pengkategorian perkembangan motorik sudah sesuai bila dilihat dari teori Morrison (1988, pp.92-93) sebagai berikut, "Motor development is classified according to the types of muscles involved in movements." Pada usia dini kemampuan motorik kasar terlihat lebih cepat Berkembang bila dibandingkan dengan motorik halus. Kegiatan motorik kasar dilakukan anak mulai dari setelah selesai ikrar, dalam pembelajaran inti, dan waktu istirahat sebelum makan yang dikembangkan lebih pada kemampuan bergerak secara koordinasi.

Kesempatan yang diberikan guru untuk mengembangkan kegiatan motorik kasar anak dalam bergerak secara koordinasi cukup besar. Kegiatan yang dilakukan untuk mengembangkan kemampuan motorik anak yaitu, senam bersama di hari Rabu, kegiatan motorik setelah ikrar sebelum antri memasuki kelas, dan kegiatan di akhir tahun dengan menampilkan gerak dan lagu.

Untuk motorik halus perlu dilakukan dalam beberapa tahap pertama meremas, membuat coretan, mengunting, menggambar bentuk dan yang terakhir anak dapat menulis. Meskipun di tingkat PAUD kegiatan menulis tidak diperkenankan, namun sebagai bentuk kesiapan untuk jenjang berikutnya anak selalu dilatih untuk melenturkaan jari-jarinya. Bagi kelas Kelompok Bermain kegiatan ini lebih banyak dilakukan dibandingkan di kelas TK.

Apabila perkembangan motorik halus anak bila dilihat dari teori kematangan anak menurut Morrisson (1988, p.93), kemampuan yang seharusnya dikuasai pada usia anak 3 tahun memasukkan sesuatu sebanyak 12 butir ke dalam botol selama 26 detik (perempuan) dan 24 detik (laki-laki). Namun perlengkapan motorik halus terutama bijibijian dari ukuran kecil-besar tidak tersedia lagi. Sehingga kemampuan motorik anak lebih banyak berkembang pada kemampuan fisik seperti melompat, menendang, berlari, dan berjalan. Sehingga perkembangan motorik yang paling menonjol pada anak lebih kepada motorik kasar.

Aspek perkembangan motorik halus anak akan lebih maksimal bila penyedian alat permainan untuk pengembangan motorik halus bisa diperbanyak dan disesuaikan dengan tahap perkembangan anak. Kegiatan yang akan dilakukan memperhatikan media yang digunakan, seperti mengayam, kegiatan mencocok, besarnya gunting di kelas $\mathrm{KB}$ akan berbeda tingkat kesulitannya dengan di TK A atau TK B.

\section{PENUTUP}

\section{Simpulan}

Proses pembelajaran yang telah dilaksanakan dilakukan dengan melalui tahapan perencanaan, pelaksanaan, dan evaluasi kegiatan pembelajaran. Dalam proses perencanaan telah terlihat alur kurikulum dengan memadukan Kurikulum Pengembangan Pribadi Muslim (KPPM) yang dimiliki dengan standar isi Permen Diknas No. 58 tahun 2009. Pembelajaran yang dilakukan menggunakan tema di setiap termnya dan dipadukan dengan kegiatan di luar struktur kurikulum. Dalam proses pembelajaran kegiatan yang dilakukan masih dalam kegiatan pembiasaan. Dalam proses evaluasi metode penilaian menggunakan criteria $\mathrm{BM}, \mathrm{MB}, \mathrm{BSH}$, dan BSB dengan menggunakan tanda bintang dan langsung masuk kedalam reapitulasi nilai.

Pada aspek perkembangan anak, kegiatan yang dilakukan untuk menstimulusnya yaitu, kegiatan sharing di pagi hari untuk pengembangan aspek kognitif anak, antri dan berbagi mainan maupun makanan untuk perkembangan sosial emosional. Sedangkan perkembangan bahasa dengan kegiatan mengenal keaksaraan, dan kegiatan senam di pagi hari, kegiatan bermain setelah ikrar, serta kegiatan gerak dan lagu diakhir tahun dilakukan untuk pengembangan motorik kasar anak.

\section{Saran}

Berdasarkan hasil dan temuan yang diperoleh serta dengan memperhatikan ke- 
terbatasan penelitian, saran yang disampaikan adalah sebagai berikut: (1) perlunya penekanan akan kebermaknaan kegiatan yang menekankan kepda tujuan serta alasan akan kegiatan pembelajaran yang dilakuakn oleh anak. (2) Pengembangan kemampuan anak akan lebih maksimal dengan variasi kegiatan dan media yang digunakan dan disesuiakan denga tahap perkembanga anak.

\section{DAFTAR PUSTAKA}

Broström, Stig. (2006). Curriculum In Preschool. International Journal of Early Childhood, 2006, 38, 1, Research Library, p.65.

Bogdan, Robert C. \& Biklen, S. K. (1992). Qualitative Research for Education: An Intriduce to Theory and Menthod. Boston: Allyn and Bacon.

Goswami, Usha. (2010). The Willey-Blackwell Handbook of Childhood Cognitive Development. Second Edition. New York: A John Willey \& Sons, Ltd.

Hedge, Archana V. \& Cassidy, Deborah J. (2009). Kindergaten Teachers' Perspectives on Developmentally Appropriate Practices (DAP): A Study Conduted in Mumbai (India). Journal of Research in Childhood Education, Spring 2009, Vol. 23, No. 3, Research Library, pg. 367.

Hurlock, Elizabeth B. 1990. Psikologi Perkembangan Suatu Pendekatan Sepanjang Rentang Kehidupan. Edisi Ketiga. Jakarta: Erlangga.
Kostelnik, Marjorie J. Soderman, Anne K. \& Whiren, Alice Phipps. 1999. Developmentally Appropriate Curriculum. Best Practices in Early Childhood Education. New Jersey: PrenticeHall, Inc.

Morisson, George S. (1988). Early Childhood Education Today. Fourth Edition. Columbus: Merrill Publishing Company.

Morisson, George S. (1988). Education and Development of Infants, Toddlers, and Preschoolers. Glenview: Scoot, Foresman and Company.

NAEYC. 2009. Developmentally Appropriate Practice in Early Childhood Program Serving Children from Birth through Age 8. A Position statement of the National Association for the Educational of Young Children. Adopted. 2009.

Roopnarine, Jaipul L. \& Johnson, James E. 2011. Pendidikan anak usia dini. Dalam berbagai pendekatan. (Terjemahan Sari Narulita).

Santrock, John W. (1980). Life-Span Development. Perkembangan Masa Hidup. Edisi Ke lima. Jakarta: Erlangga.

Umek, Ljubica Marjanovič, Fekonja, Urŝka, Katja BAJC, et al. (2006). The Effect of Preschool and Quality of Home Literacy Environment on The Child's Language Development. Studia Psychologica. 48, 2006, 2. 